\title{
THE PROFESSIONAL SATISFACTION OF THE NURSING TEAM VS. WORK CONDITIONS AND RELATIONS: A RELATIONAL STUDY ${ }^{1}$
}

\author{
Danielle Wisniewski², Eraldo Schunk Silva ${ }^{3}$, Yolanda Dora Martinez Évora ${ }^{4}$, Laura Misue Matsuda ${ }^{5}$
}

\footnotetext{
${ }^{1}$ Article resulting from the Dissertation - Work Conditions and relations of the nursing team in the perspective of professional satisfaction, presented to the Programa de Pós Graduação em Enfermagem, Universidade Estadual de Maringá (UEM), in 2013.

${ }_{2}^{2}$ M.Sc. in Nursing. Professor Departamento de Enfermagem, Universidade Estadual do Centro Oeste. Guarapuava, Paraná, Brazil. E-mail: daniwisni@gmail.com

${ }^{3}$ Ph.D in Agronomy. Coordinating Professor Pós-Graduação em Estatística, UEM. Maringá, Paraná, Brazil. Email: eraldoschunk@ gmail.com

${ }^{4}$ Ph.D in Nursing. Full Professor Escola de Enfermagem de Ribeirão Preto, Universidade de São Paulo. Ribeirão Preto, São Paulo, Brazil. Email: yolanda@eerp.usp.br

${ }^{5}$ Ph.D in Nursing. Professor. Departamento de Enfermagem Programa de Pós Graduação em Enfermagem, UEM. Maringá, Paraná, Brazil. Email: lmisue@terra.com.br
}

\begin{abstract}
This relational, transversal and quantitative study aimed to test the association of sociodemographic and professional variables with the job satisfaction of hospital nursing teams and to ascertain whether the work relations and conditions influenced the professional satisfaction of the same teams. A total of 212 subjects participated, responding to the Research into Work Conditions and Relations questionnaire in the period February - June 2013. The data were treated using descriptive statistical analysis and bivariate analysis, using Fisher's exact test and the Chi-squared test. It was observed that there was statistical significance $(p<0.05)$ between dissatisfaction and sex, time since graduation, work department and shift, number and type of employment links, team size, safety, occupational health, department accommodation, task distribution, professional encouragement, valorization of the work and motivation. It was concluded that inadequate work conditions and relations were associated with nursing professionals' job dissatisfaction.
\end{abstract}

DESCRIPTORS: Job satisfaction. Work conditions. Nursing. Occupational health.

\section{SATISFAÇÃO PROFISSIONAL DA EQUIPE DE ENFERMAGEM $X$ CONDIÇÕES E RELAÇÕES DE TRABALHO: ESTUDO RELACIONAL}

RESUMO: Estudo relacional, transversal, quantitativo que objetivou testar a associação de variáveis sociodemográficas e profissionais com a satisfação no trabalho de equipes de enfermagem hospitalar e, verificar se as relações e as condições de trabalho influenciam na satisfação profissional das mesmas equipes. Participaram 212 sujeitos que responderam ao questionário Pesquisa das Condições e Relações de Trabalho, no período entre fevereiro a junho de 2013. Os dados foram tratados por meio de análise estatística descritiva e bivariada, com uso do Teste Exato de Fisher e Qui-Quadrado. Constatou-se que houve significância estatística $(p<0,05)$ entre insatisfação e sexo, tempo de formação, setor e turno de trabalho, número e tipo de vínculo, tamanho da equipe, segurança e medicina do trabalho, acomodações do setor, distribuição das tarefas, estímulo profissional, valorização laboral e motivação. Concluiu-se que inadequadas condições e relações no trabalho se associaram à insatisfação laboral de profissionais de enfermagem.

DESCRITORES: Satisfação no trabalho. Condições de Trabalho. Enfermagem. Saúde do Trabalhador.

\section{SATISFACCIÓN DE LOS PROFESIONALES DE ENFERMERÍA X CONDICIONES Y RELACIONES DE TRABAJO: ESTUDIO RELACIONAL}

\begin{abstract}
RESUMEN: Estudio relacional, transversal y cuantitativo. Tuvo como objetivo probar la asociación de variables sociodemográficas y profesionales con satisfacción en el trabajo de equipos de enfermería del hospital, y también comprobar si las relaciones y las condiciones de trabajo influyen en la satisfacción laboral de los mismos equipos. Participó en 212 sujetos que respondieron al cuestionario de la encuesta Condiciones y las relaciones laborales en el periodo de febrero a junio de 2013. Los datos fueron analizados utilizando estadística descriptiva y análisis inferencial utilizando el Test Exacto de Fisher y Chi-Cuadrado. Se encontró significación estadística $(p<0,05)$ entre la insatisfacción y el sexo, tiempo de la graduación, el sector y turno de trabajo, el número y tipo de contrato de trabajo, el tamaño del equipo, seguridad y salud ocupacional, sector del alojamiento, distribución de tareas, estímulo profesional, la motivación y la apreciación laboral. Se concluye que las condiciones inadecuadas y relaciones en el trabajo estaban asociadas con la insatisfacción laboral de las enfermeras.
\end{abstract}

DESCRIPTORES: Satisfacción en el trabajo. Condiciones de trabajo. Enfermería. Salud laboral. 


\section{INTRODUCTION}

Work is one of the means that allows people to be recognized as unique individuals in society and, based on the role occupied, people tend to seek satisfaction (personal or job-related) and to guarantee their quality of life.

Regarding work, this may be defined as a human, manual or intellectual activity, requiring efforts and which contributes to meeting one's own needs and/or those of third parties. ${ }^{1}$ In the context of nursing work, the job is mediated through interaction and communication between professionals and patients, thus constituting a human process, which is essentially intersubjective $^{2}$; and in this perspective, the work must be analyzed in terms of the items which constitute it, as satisfaction and dissatisfaction in relation to it mean the result of the interaction between the environment, the worker, and the work components. ${ }^{3}$

In relation to satisfaction of work or job satisfaction, this consists of feelings related to the various aspects or facets of the job; and is considered to be an indicator of physiological and/or emotional well-being. ${ }^{4}$ In other words, the concept of job satisfaction is understood as the feeling of contentment which the worker manifests through his or her work, which can be positive (satisfaction) or negative (dissatisfaction).

In relation to the dimensions of the job, it is possible to divide them in two large groups: 1) Events and conditions and; 2) Agents. The first group - events and conditions, that is, working conditions - addresses aspects of the job such as: payment; promotion; recognition; the working environment; resources available (time, money, equipment, support, the working day, work shifts); physical conditions (noise, ventilation, humidity, temperature, physical layout) and safety (absence of risks). ${ }^{5}$

The second group, the agents, or work relations, encompasses factors such as: relationships between colleagues and subordinates; communication with superiors; relation with the sharing of values; professional recognition; participation in decision-making; respect to staff as human beings; and the policies and mission of the institution. ${ }^{5}$

Regarding the nursing professionals' work conditions and relations, some studies, ${ }^{6-8}$ addressing their impacts on the team's quality of life and satisfaction, mention that if the work conditions and relations are inadequate, the nursing worker tends to present psychological and physical strain; ${ }^{6}$ musculoskeletal problems; and high rates of absenteeism and illness. ${ }^{8}$ Otherwise, if these are adequate, the tendency is that job satisfaction and better quality of life occur for the worker. ${ }^{6-8}$

In taking into account that job dissatisfaction can entail potential harm to the worker's health, it is necessary to undertake an investigation into the issue and also into the factors which generate (dis-)satisfaction, such as those referent to the working conditions and to the interpersonal relationships in the work environment. In the light of this premise, studies related to this issue are important as they produce information which makes it possible to understand the changes necessary in the work context, and support strategies for preventing harm to the health system's workforce and clients/users.

Based on the considerations presented, this study is grounded in the following question: Is it the case that the hospital nursing team's work conditions and relations are related to the (dis-) satisfaction of the hospital workers? In order to answer this question, the present study aimed to test the association between sociodemographic and professional variables and the job satisfaction of hospital nursing teams, and to ascertain whether the work relations and conditions influence these teams' professional satisfaction.

\section{MATERIAL AND METHODS}

This is a descriptive, relational, transversal and quantitative study, undertaken in three hospitals, termed philanthropic $(\mathrm{PhH})$; private $(\mathrm{PH})$; and public $(\mathrm{PbH})$, in a municipality in the rural region of the Brazilian state of Paraná.

The $\mathrm{PhH}$ has 225 beds, of which 136 are set aside for attending patients of the Unified Health System (SUS), while the remaining 89 beds are for private treatment and that paid for by health insurance schemes. The nursing workforce was made up of 420 professionals, of whom 43 were nurses and 377 were mid-level providers.

The $\mathrm{PH}$ had 79 beds, attending private patients and patients with health insurance. The nursing team was made up of 243 professionals, among whom there were 77 nurses and 166 midlevel providers.

The $\mathrm{PbH}$ is accredited with the Unified Health System (SUS), is the center of excellence 
for 29 municipalities, and prioritizes care, teaching and research activities. At the time of the study, it had 135 beds and 240 nursing professionals. Of these 70 were nurses and the remaining 170 were mid-level providers.

The study population was made up of nursing professionals from the Surgical Center (SC), the Adult Intensive Care Unit (A-ICU), and the Emergency Room (ER), who met the following criteria: to have worked as a nursing professional in one of these departments for at least six months and to have a formal employment contract in the establishment. As a result, 212 professionals participated as research subjects, of whom 64 were nurses and 148 were professionals of the technical team.

In this study, the technical team was made up of auxiliary nurses and nursing technicians, and also of staff nurses. These last only undertake the provision of direct activity to the patient, the exercising of administrative activities such as management, coordination, leadership, technical responsibility and liability for the technical team therefore being vetoed. ${ }^{9}$

This study was undertaken using the Survey technique, in which data collection took place through the Work Conditions and Relations Research questionnaire, of the Brazilian Program for Health Services Evaluation (PNASS), of the Health Ministry. ${ }^{10}$ It is emphasized that, for the purposes of this study, small adaptations were made to the instrument, as the same presented responses to the questions in the form of a fiveitem Likert scale: Very Good; Good; Neutral; Bad and Very Bad, which hindered the quantification of the value for the representation of each item. After the analysis of the instrument by a professional statistician, followed by discussions with professional nurses, the answer scale was reorganized to a scale form (00-10 points), such that the statistical analysis presented the data in a way that was more consistent with the objectives proposed, thus making it possible to observe the occurrence or not of relations between the dependent variable (satisfaction) and the remaining variables (independent).

It is worth remembering that the type of adaptation undertaken in the instrument is recommended by the Health Care Secretariat, so as to thoroughly review the instruments used and to ensure the use of more objective terminology, with clearer editing for the establishing of criteria and standards which promote evaluation in health. ${ }^{10}$

In order to confirm the instrument's liability, prior to its use, the questionnaire was subjected to a pilot test with 17 nursing staff from hospitals which did not belong to the sample established, which indicated that it was suited in terms of presentation, understanding of the questions, and issuing of the answers.

Data collection was undertaken in the period February - June 2013, when the researcher, prior to handing the questionnaire to the respondent, provided clarification regarding the research and, following that, requested the same to proceed to reading and signing the Terms of Free and Informed Consent (TFIC), in two copies. Of these, one remained in the possession of the researcher and the other was handed to the worker. The questionnaire was answered in a private place, during each participant's work shift.

The data were organized and tabulated using the program Microsoft Office Excel® 2007 and were later imported to the Statistical Analysis System ${ }^{\circledR}(\mathrm{SAS})$ program for the undertaking of the statistical analyses. After the descriptive analysis (univariate), bivariate analyses were also undertaken (Chi-squared and Fisher's exact test Fisher between the dependent variable (satisfaction) and the other variables, considered independent (sex, age, marital status, number of children, income, educational level, professional category, length of service in the institution, department where the staff member worked, weekly hourly workload, type of institution). For each characteristic of the population studied, a level of significance of $p<0.05$ was established, with a respective confidence interval of $95 \%$.

This study was approved under number 207,365/2013, by the Standing Ethics Committee in Research Involving Human Beings, of Maringá State University.

\section{RESULTS}

A total of 212 nursing professionals participated in this study, the results of which are presented in the form of four tables.

Table 1 contains data inherent to the relation of the sociodemographic characteristics with Job (dis-)satisfaction. In accordance with the statistical test applied, the variable of sex was the only one which presented statistical significance. 
Table 1 - Relation between the sociodemographic variables and Job (dis-)satisfaction in the nursing team, by hospital. Maringá (PR), 2013

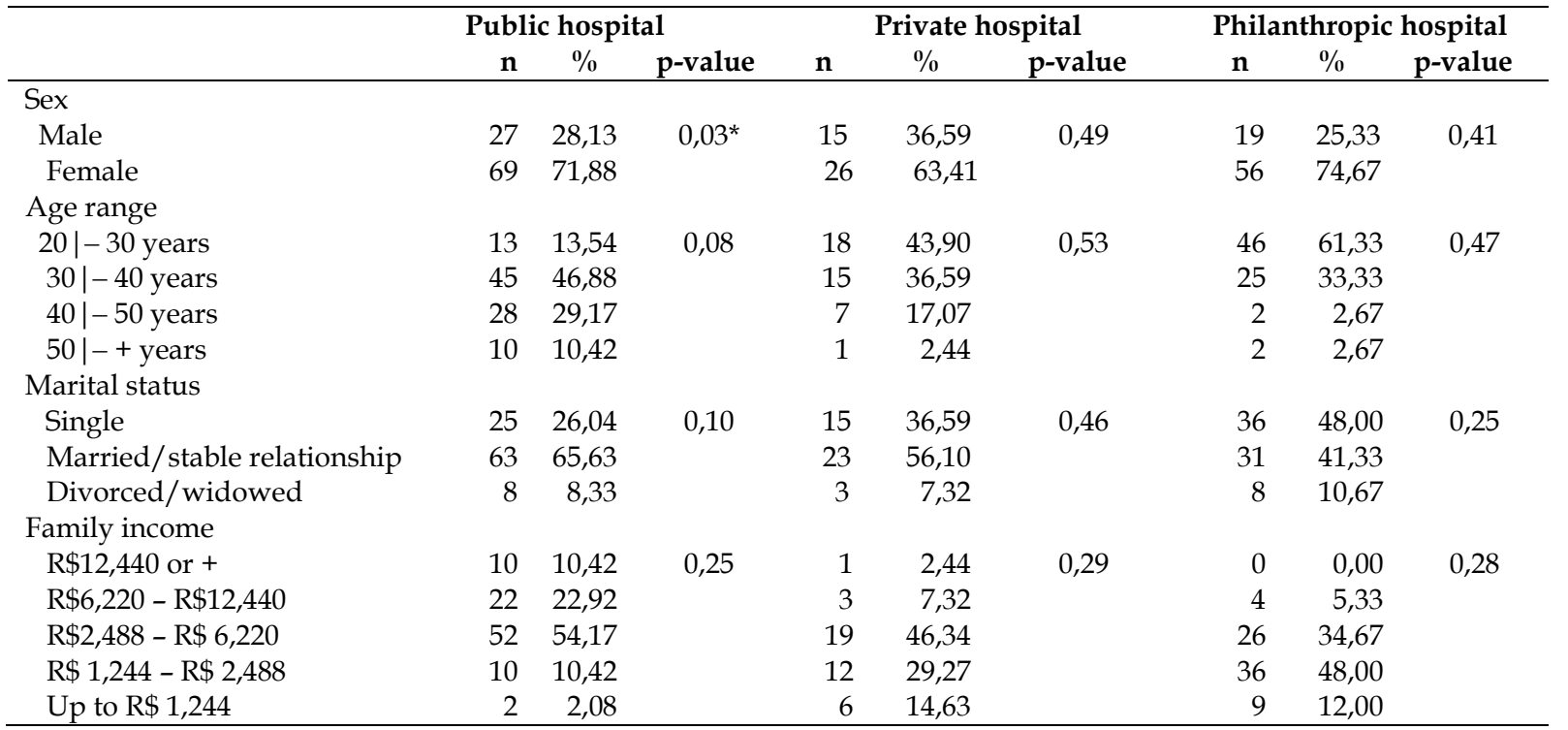

* Statistical significance, $\mathrm{p}<0.05$.

Table 2 presents data referent to the relation between the professional characteristics and Job (dis-)satisfaction, in which one may see that time since graduation; work department and shift; and number and type of employment are the variables which obtained statistical significance.

Table 2 - Relation between the professional variables and Job (dis-)satisfaction of the nursing team, by hospital. Maringá (PR), 2013

\begin{tabular}{|c|c|c|c|c|c|c|c|c|c|}
\hline \multirow[t]{2}{*}{ Variable } & \multicolumn{3}{|c|}{ Public hospital } & \multicolumn{3}{|c|}{ Private hospital } & \multicolumn{3}{|c|}{ Philanthropic hospital } \\
\hline & $\mathbf{n}$ & $\%$ & p-value & $\mathbf{n}$ & $\%$ & p-value & $\mathbf{n}$ & $\%$ & p-value \\
\hline \multicolumn{10}{|l|}{ Professional category } \\
\hline Nurses & 36 & 37,50 & 0,52 & 8 & 19,51 & 1,00 & 20 & 26,67 & 0,59 \\
\hline $\begin{array}{l}\text { Nursing technician/ } \\
\text { auxiliary nurse/staff nurse }\end{array}$ & 60 & 62,50 & & 33 & 80,49 & & 55 & 73,33 & \\
\hline \multicolumn{10}{|l|}{ Time since qualification } \\
\hline$<5$ years & 10 & 10,42 & 0,09 & 24 & 58,54 & $0,04^{*}$ & 42 & 56,00 & 0,94 \\
\hline Between 5-10 years & 25 & 26,04 & & 9 & 21,95 & & 25 & 33,33 & \\
\hline$\geq 10$ & 61 & 63,54 & & 8 & 19,51 & & 8 & 10,67 & \\
\hline \multicolumn{10}{|l|}{ Department } \\
\hline $\mathrm{SC}$ & 18 & 18,75 & 0,55 & 15 & 36,59 & $0,03^{*}$ & 29 & 38,67 & 0,28 \\
\hline ER & 49 & 51,04 & & 9 & 21,95 & & 19 & 25,33 & \\
\hline ICU & 29 & 30,21 & & 17 & 41,46 & & 27 & 36,00 & \\
\hline \multicolumn{10}{|l|}{ Shift } \\
\hline Morning & 25 & 26,04 & 0,62 & 13 & 31,71 & 0,27 & 18 & 24,00 & $0,02 *$ \\
\hline Afternoon & 26 & 27,08 & & 16 & 39,02 & & 30 & 40,00 & \\
\hline Night & 34 & 35,42 & & 11 & 26,83 & & 20 & 26,67 & \\
\hline Two shifts & 11 & 11,46 & & 1 & 2,44 & & 7 & 9,33 & \\
\hline \multicolumn{10}{|l|}{ N. of emp. links } \\
\hline One & 69 & 71,88 & $0,004^{*}$ & 31 & 75,61 & 0,51 & 47 & 62,67 & 0,77 \\
\hline Two & 25 & 26,04 & & 10 & 24,39 & & 25 & 33,33 & \\
\hline Three & 2 & 2,08 & & - & - & & 3 & 4,00 & \\
\hline \multicolumn{10}{|l|}{ Type of link } \\
\hline CLT & - & - & $0,004^{*}$ & 37 & 90,24 & 0,80 & 75 & 100,00 & $\dagger$ \\
\hline Public examination & 78 & 81,25 & & - & - & & - & - & \\
\hline $\begin{array}{l}\text { Tertiarized/temporary } \\
\text { contract }\end{array}$ & 18 & 18,75 & & 4 & 9,76 & & - & - & \\
\hline
\end{tabular}

\footnotetext{
* Statistical significance, $\mathrm{p}<0.05$; † Variables not combined. CLT: Consolidation of Labor Laws.
} 
Table 3 contains data referent to the relation between (Dis-)satisfaction and the constitutive elements of the work conditions. The values indicate that the dimensioning of the team; the accommodation of the department; the safety for undertaking the work and; occupational health have statistical significance with the nurses' Job (dis-)satisfaction.

Table 3 - Relation between (Dis-)satisfaction and work conditions of the nursing team of three hospitals. Maringá (PR), 2013

\begin{tabular}{|c|c|c|c|c|c|c|c|c|c|}
\hline \multirow{2}{*}{ Working conditions } & \multicolumn{3}{|c|}{ Public hospital } & \multicolumn{3}{|c|}{ Private hospital } & \multicolumn{3}{|c|}{ Philanthropical hospital } \\
\hline & $\mathrm{S}^{\dagger}$ & $\mathbf{I}^{\ddagger}$ & p-value & $S^{\dagger}$ & $\mathbf{I}^{\ddagger}$ & p-value & $\mathrm{S}^{\dagger}$ & $\mathbf{I}^{\ddagger}$ & p-value \\
\hline \multicolumn{10}{|c|}{ Workload in the hospital } \\
\hline Negative & 27,59 & 47,37 & \multirow{2}{*}{0,0534} & 39,29 & 38,46 & \multirow{2}{*}{1,0000} & 25,53 & 35,71 & \multirow{2}{*}{0,4338} \\
\hline Positive & 72,41 & 52,63 & & 60,71 & 61,54 & & 74,47 & 64,29 & \\
\hline \multicolumn{10}{|c|}{ Size (dimensioning) of the team } \\
\hline Negative & 32,76 & 55,26 & \multirow{2}{*}{$0,0355^{*}$} & 53,57 & 38,46 & \multirow{2}{*}{0,5055} & 23,40 & 46,43 & \multirow{2}{*}{$0,0453^{*}$} \\
\hline Positive & 67,24 & 44,74 & & 46,43 & 61,54 & & 76,60 & 53,57 & \\
\hline \multicolumn{10}{|c|}{ Safety for undertaking the work } \\
\hline Negative & 6,90 & 28,95 & \multirow{2}{*}{$0,0078^{*}$} & 21,43 & 23,08 & \multirow{2}{*}{1,0000} & 6,38 & 32,14 & \multirow{2}{*}{$0,0069^{*}$} \\
\hline Positive & 93,10 & 71,05 & & 78,57 & 76,92 & & 93,62 & 67,86 & \\
\hline \multicolumn{10}{|c|}{ Accommodation and furniture of the unit/department } \\
\hline Negative & 41,38 & 65,79 & \multirow{2}{*}{$0,0229^{*}$} & 28,57 & 38,46 & \multirow{2}{*}{0,7197} & 6,38 & 25,00 & \multirow{2}{*}{$0,0339^{*}$} \\
\hline Positive & 58,62 & 34,21 & & 71,43 & 61,54 & & 93,62 & 75,00 & \\
\hline \multicolumn{10}{|c|}{ Hygiene of the unit/department where employee works } \\
\hline Negative & 5,17 & 15,79 & \multirow{2}{*}{0,1485} & 10,71 & 15,38 & \multirow{2}{*}{0,6448} & 6,38 & 10,71 & \multirow{2}{*}{0,6652} \\
\hline Positive & 94,83 & 84,21 & & 89,29 & 84,62 & & 93,62 & 89,29 & \\
\hline \multicolumn{10}{|c|}{ Availability of materials and equipment in the unit/department } \\
\hline Negative & 12,07 & 23,68 & \multirow{2}{*}{0,1660} & 25,00 & 15,38 & \multirow{2}{*}{0,6925} & 6,38 & 7,14 & \multirow{2}{*}{1,0000} \\
\hline Positive & 87,93 & 76,32 & & 75,00 & 84,62 & & 93,62 & 92,86 & \\
\hline \multicolumn{10}{|c|}{ Hospital's occupational health } \\
\hline Negative & 27,59 & 44,74 & \multirow{2}{*}{0,1234} & 28,57 & 38,46 & \multirow[t]{2}{*}{0,7197} & 8,51 & 32,14 & 4010 \\
\hline Positive & 72,41 & 55,26 & & 71,43 & 61,54 & & 91,49 & 67,86 & 0,0127 \\
\hline Salary & & & & & & & & & \\
\hline Negative & 5,17 & 10,53 & & 39,29 & 61,54 & & 48,94 & 67,86 & \\
\hline Positive & 94,83 & 89,47 & 0,429 & 60,71 & 38,46 & & 51,06 & 2,14 & 0,1501 \\
\hline
\end{tabular}

†Satisfaction; ${ }^{\ddagger}$ Dissatisfaction; * Statistical significance, $\mathrm{p}<0.05$.

Table 4 subsequently compares the factors which make up the relationship in the work and the (Dis-)satisfaction in the hospital environment, where a statistical relation is observed between Job (dis-)satisfaction and the distribution of the team's tasks; encouragement given by the hospital; and valuing of the work by the immediate management. 
Table 4 - Comparison between the work relations and (Dis-)satisfaction of the nursing team of three hospitals. Maringá (PR), 2013

\begin{tabular}{|c|c|c|c|c|c|c|c|c|c|}
\hline \multirow{2}{*}{ Working relations } & \multicolumn{3}{|c|}{ Public hospital } & \multicolumn{3}{|c|}{ Private hospital } & \multicolumn{3}{|c|}{ Philanthropical hospital } \\
\hline & S & $\mathbf{I}^{\ddagger}$ & p-value & $\mathrm{S}^{\dagger}$ & $\mathbf{I}^{\ddagger}$ & p-value & $\mathrm{S}^{\dagger}$ & $\mathbf{I}^{\ddagger}$ & p-value \\
\hline \multicolumn{10}{|c|}{ Distribution of tasks in your team } \\
\hline Negative & 20,69 & 42,11 & & 35,71 & 30,77 & & 12,77 & 39,29 & \\
\hline Positive & 79,31 & 57,89 & $0,0378^{*}$ & 64,29 & 69,23 & 1,0000 & 87,23 & 60,71 & $0,0111^{*}$ \\
\hline \multicolumn{10}{|c|}{ Relationship with immediate management } \\
\hline Negative & 15,52 & 18,42 & & 17,86 & 15,38 & & 2,13 & 10,71 & \\
\hline Positive & 84,48 & 81,58 & 0,7825 & 82,14 & 84,62 & 1,0000 & 97,87 & 89,29 & 0,1435 \\
\hline \multicolumn{10}{|c|}{ Encouragement given by the hospital } \\
\hline Negative & 29,31 & 52,63 & & 32,14 & 38,46 & & 21,28 & 46,43 & \\
\hline Positive & 70,69 & 47,37 & $0,0317^{*}$ & 67,86 & 61,54 & 0,7337 & 78,72 & 53,57 & $0,0372^{*}$ \\
\hline \multicolumn{10}{|c|}{ Valorization of the work by the immediate management } \\
\hline Negative & 27,59 & 31,58 & & 25,00 & 46,15 & & 8,51 & 28,57 & \\
\hline Positive & 72,41 & 68,42 & 0,8187 & 75,00 & 53,85 & 0,2797 & 91,49 & 71,43 & $0,0468^{*}$ \\
\hline \multicolumn{10}{|c|}{ Compatibility between the activities undertaken and the job for which the worker was contracted } \\
\hline Negative & 5,17 & 13,16 & & 7,14 & 7,69 & & 4,26 & 17,86 & \\
\hline Positive & 94,83 & 86,84 & 0,2577 & 92,86 & 92,31 & 1,0000 & 95,74 & 82,14 & 0,0947 \\
\hline \multicolumn{10}{|c|}{ Motivation to continue in the job } \\
\hline Negative & 31,03 & 39,47 & & 21,43 & 53,85 & & 14,89 & 28,57 & \\
\hline Positive & 68,97 & 60,53 & 0,5102 & 78,57 & 46,15 & 0,0693 & 85,11 & 71,43 & 0,2319 \\
\hline
\end{tabular}

*Statistical significance, $\mathrm{p}<0.05 ; \uparrow$ Satisfaction; $\ddagger$ Dissatisfaction.

\section{DISCUSSION}

In the data from Table 1 (sociodemographic), emphasis should be placed on sex and salary, given that as the population was predominantly female the women's dissatisfaction was plausible; the cause for this could be the fact that many of them, in addition to domestic chores, work in the formal job market so as to improve the family income. This double or even triple workday tends to generate physical and mental exhaustion, and shortage of time to dedicate oneself to personal interests, which tend to result in stress and dissatisfaction. ${ }^{11}$

In relation to the salary, attention is drawn to the great divergence between the workers in the three hospital institutions, as the higher salaries are concentrated in the public hospital. In spite of the difference between pay, no statistical relationship was observed between this variable and satisfaction.

The fact that the literature ${ }^{6}$ indicates that pay does not cause dissatisfaction in nursing can and must be contested, as - as well as being a profession which often supports the survival of entire families - due to being related directly to the availability of elements which meet basic human needs, the salary, without doubt, tends to be directly reflected in the level of professional satisfaction of nurses. ${ }^{6}$

It stands out that nursing, until the 1850's, was a profession geared towards abnegation, humility, discipline and philanthropy, staffed mainly by women ${ }^{12}$ and that -perhaps because of this - approaches regarding salary remain omitted or neglected. Another fact is that, in present-day society, in spite of nursing being recognized as a science, it still bears traces of the past and many people believe that in order to work in this profession one needs merely a natural gift rather than preparation and specific and in-depth scientific knowledge. This ignorance regarding training and the true role of the professional nurse is definitely one of the factors which interferes in the recognition of the profession by society ${ }^{12}$ and also in its salary.

In relation to Table 2 , it is observed that dissatisfaction was presented as associated with the department of work of the private hospital. 
This data corresponds with the literature ${ }^{13}$, which indicates that, in hospital units, dissatisfaction is associated with inadequate work conditions, and the precariousness and insufficiency of material resources. In the light of this, the workers' dissatisfaction detected in this study may be related to the clinical conditions presented by the patients at risk of death and to the possible difficulty of the workers in undertaking care actions when faced with a disfavorable prognosis and/or one of risk. In the other hospitals - philanthropic and public - dissatisfaction was not statistically related to this variable, although this does not mean that all the professionals in these hospitals were satisfied.

Remaining on issues referent to the professionals' characteristics, the work shift in the philanthropic hospital was presented as significant for dissatisfaction. As a result of this, it is emphasized that it is important to take into account the work shift in the perspective of job satisfaction, as the workers who work the night shift need to change their living routine - in particular that of sleeping - which is the main issue responsible for rest. The literature corresponds with this finding and indicates that night work negatively influences nursing professionals' capacity for work ${ }^{14}$ as it triggers physical strain, changes in circadian rhythms, insufficient time for sleeping, reduction of cognitive capacity and capacity to undertake tasks, which contribute to the occurrence of accidents and illnesses related to the job. ${ }^{4}$

Besides the work shift, the number of employment links in the $\mathrm{PbH}$, and the type of link in the $\mathrm{PbH}$ and $\mathrm{PhH}$, were also associated with dissatisfaction. In this aspect, the data indicate that the individuals with temporary contracts tend to be dissatisfied, as found in a study undertaken in a general hospital in Paraná which aimed to investigate the influence of sociodemographic and professional variables regarding nursing professionals' capacity for the work with one job and with more than one job. ${ }^{14}$

The employment link, represented by temporary work contracts, the type of link of the $\mathrm{PhH}$ and $\mathrm{PH}$, can create instability, insecurity and fear for the professional, related to losing the job - and in these cases there is a higher chance of dissatisfaction in the work. ${ }^{15}$ A contrary fact can occur with workers who are contracted through public examinations, which is the case with the
$\mathrm{PbH}$, which guarantees job security ${ }^{*}{ }^{16}$ In addition to this, the majority of the public positions have a plan of duties and salaries, which can positively influence the workers' satisfaction, including them to seek professional improvement.

In relation to safety for undertaking the work in the $\mathrm{PbH}$ and $\mathrm{PhH}$, and the $\mathrm{PhH}^{\prime}$ 's occupational health department, when related to the work conditions (Table 3), both demonstrated statistical significance for dissatisfaction. These findings match the administrative approach, which indicates that the staff, commonly, are dissatisfied with the medical-hospital care, the security, and the occupational health. ${ }^{15}$ Regarding safety and occupational health, it is important that the institutions should have a team of specialists in this area, with a view to the prevention of accidents, who guide the workers in relation to the occupational risks, provide safety in the undertaking of activities, and ensure support in the event of workplace accidents. ${ }^{7}$ Based on this understanding, it is possible to infer that some professionals of this study lack support regarding safety and occupational health, which promotes job dissatisfaction.

Still in relation to Table 3 , the data indicate that poor dimensioning of the staff of the $\mathrm{PbH}$ and $\mathrm{PhH}$ is associated with dissatisfaction. The appropriate dimensioning of the nursing team in Brazilian health institutions is supported by the Law of Professional Nursing Exercising, ${ }^{17}$ however, the prerogatives found in this are not respected by many institutions ${ }^{18}$ and this may result in work burden for the professional, with consequent job dissatisfaction. With a view to providing better working conditions, it is necessary that health institutions should systematically undertake the dimensioning of the nursing workforce, in particular of the category of nurses. ${ }^{18}$

Regarding the work relations (Table 4), the variables which were presented as important predictors for dissatisfaction were: the encouragement given by the hospital to continue in the institution ( $\mathrm{PH}$ and $\mathrm{PhH})$; and the valuing of the work by the management $(\mathrm{PhH})$. These data are similar to the results of another study undertaken in a public general hospital of Rio de Janeiro, with the nursing professionals, which observed that the variable of motivation, leadership style and interpersonal relationships were the elements responsible for $64 \%$, on average, of the nursing

It is exceedingly rare for an employee of a public hospital to lose their job. Translator's note. 
workers' dissatisfaction. ${ }^{19}$ Based on this argument, it is appropriate to emphasize that the company should provide the staff member with a healthy working environment, based on participation and recognition for the work undertaken, as an environment which incorporates its staff members in resolving problems - including in decision-making processes - tends to promote democracy and also job satisfaction. ${ }^{20}$

Because of the fact that working takes up a large part of peoples' lives, it is necessary for leaders to pay attention to promoting better working conditions, whether in the ambit of the workplace's structure or in the ambit of the relationship between the team members.

\section{CONCLUSION}

This study indicated that inappropriate and inadequate working conditions are associated with job dissatisfaction among nursing professionals who work in critical units (Surgical Center, Intensive Care Unit and Emergency Room). Among the socioeconomic variables investigated, emphasis was placed on sex; among the professional variables, emphasis was placed on time since qualification, the work department and shift, and the number of employment links and type of employment link. In relation to the working conditions, emphasis is placed on those related to the size of the team, safety and occupational health, and the department's accommodation. Regarding the work relations, dissatisfaction was evidenced with the distribution of tasks, professional encouragement, job valorization and motivation.

In order to minimize the scenario revealed in this study, it is suggested that the management of the institutions investigated should be alert to the factors which cause dissatisfaction. Furthermore, based on systematized data, such as that presented in this study, the institutions should invest in actions which promote job satisfaction on the part of their staff.

As a limitation of this study, the design chosen is indicated - that is, the fact that it was undertaken in three hospital institutions (public, private and philanthropic), in a single municipality, in such a way that the information obtained cannot be generalized. However, its results make it possible to increase the undertaking of studies related to the topic and also to contribute to the promotion/maintenance of nursing professionals' health and of the quality of the care.

\section{REFERENCES}

1. Moraes DB. A valorização do trabalho como condição para a efetivação do princípio da dignidade da pessoa humana: o papel do estado na valorização do trabalho [dissertação]. Marília (PR): Universidade de Marília, Programa de Mestrado em Direito; 2008.

2. Carvalho BG, Peduzzi M, Mandu ENT, Ayres JRCM. Work and Inter-subjectivity: a theoretical reflection on its dialectics in the field of health and nursing. Rev Latino-Am Enfermagem. 2012; 20(1):19-26.

3. Durrive L. A atividade humana, simultaneamente intelectual e vital: esclarecimentos complementares de Pierre Pastré e Yves Schwartz. Trab Educ Saúde. 2011; 9(sup.1):47-67.

4. Bhatnagar K, Srivastava K. Job satisfaction in healthcare organizations. Ind Psychiatry J. 2012; 21(1):75-8.

5. Locke EA. 'Job satisfaction'. In: Grunenberg M, Wall $\mathrm{T}$. Social psychology and organizational behavior. New York (US): John Wiley \& Sons; 1984. p. 93-117.

6. Negussie N, Demissie A. Relationship between leadership styles of nurse managers and nurses' job satisfaction in Jimma University Specialized Hospital. Ethiop J Health Sci. 2013; 23(1):49-57.

7. Kuzey, C. Impact of health care employees' job satisfaction on organizational performance support vector machine approach. European Jf Econ Political Stud. 2012; 5(1):65-89.

8. Tran BX, Minh HV, Hinh ND. Factors associated with job satisfaction among commune health workers: implications for human resource policies. Glob Health Action. 2013; 6(1):1-6.

9. Sindicato dos Hospitais e Estabelecimentos de Saúde de Maringá e Região. Conveção Coletiva de Trabalho, 2012-2013. Maringá (PR): SHESSMAR; 2012.

10. Ministério da Saúde (BR). Caderno do programa nacional de avaliação dos serviços de saúde. Departamento de Regulação. Avaliação e controle de sistemas - DRAC. Edição 2004/2005. Brasília (DF):MS; 2004.

11. Lorber M, Skela-Savic B. Job satisfaction of nurses in Slovenian Hospitals. Croat Med J. 2012; 53(1):263-70.

12. Avila LI, Silveira RS, Lunardi VL, Fernandes GFM Mancia JR, Silveira JT. Implicações da visibilidade da enfermagem no exercício profissional. Rev Gaúcha Enferm. 2013; 34(3):102-9.

13. Silveira RS, Funck CR, Lunardi VL, Silveira JT, Avila LI, Filho WDL, et al. Percepção dos trabalhadores de enfermagem acerca da satisfação no contexto do trabalho na UTI. Enferm Foco. 2012; 3(2):93-6.

14. Murassaki ACY, Melo WA, Matsuda LM. Influência das características sociodemográficas e ocupacionais em trabalhadores da equipe de enfermagem com um emprego e multiemprego. Cienc Cuid Saúde. 2013; XIX(2): 89-98. 
15. Chiavenato I. Gestão de Pessoas: O novo papel dos recursos humanos nas organizações. Rio de Janeiro (RJ): Elsevier; 2008.

16. Carvalho MC, Rocha FLR, Marziale MHP, Gabriel CS, Bernardes A. Work values and practices which characterize the organizational culture of a public hospital. Texto Contexto Enferm [online]. 2013 [acesso 2013 Out 27]; 22(3):746-53. Disponível em: http://www.scielo.br/pdf/tce/v22n3/v22n3a22. pdf

17. Brasil. Lei 7.498, de 25 de junho de 1986: Dispõe sobre a Regulamentação do Exercício da Enfermagem e dá outras providências. Brasília (DF): Diário Oficial da União; 1986.
18. Menegueti MG, Nicolussi AC, Scarparo AF, Campos LF, Chaves LDP, Laus AM. Dimensionamento de pessoal de enfermagem nos serviços hospitalares: revisão integrativa da literatura. Rev Eletr Enfern [online]. 2013 [acesso 2013 Out 25]; 15(2):551-63. Disponível em: http://www.fen.ufg.br/revista/ v15/n2/pdf/v15n2a30.pdf

19. Spindola T, Santos RS. O trabalho na enfermagem e seu significado para as profissionais. Rev Bras Enferm. 2005; 58(2):156-60.

20. Karino ME, Martins JT, Bobroff MCC. Reflexão sobre as políticas de saúde do trabalhador no Brasil: avanços e desafios. Cienc Cuid Saude. 2011: 10(2):395-400. 